\title{
An Analysis Study on the Impact of Behavior Changes and Efforts to Build Trust of Potential Tourist Post-Corona in Kupang
}

\author{
Fransiscus Nicodemus Naiola ${ }^{1, *}$, Pasifikus Mala Mekom² ${ }^{2}$, Fahri Reva Adiputra ${ }^{2}$, Protasius Tiberius Jehane ${ }^{2}$ \\ ${ }^{1}$ Accounting Department, ${ }^{2}$ Hospitality Department \\ State Kupang Polytechnic \\ Kupang, Indonesia \\ *fransiscus.naiola@pnk.ac.id
}

\begin{abstract}
This study aims to see changes in behaviour and efforts to build tourist trust in Kupang City after the Corona virus in Indonesia. The method of analysis of this research is a mix-method, which is exploration and implementation and dissemination. The technique of determining the sample and informants in this study were 100 tourists, with the instrument questionnaire and SPSS analysis tools. Meanwhile, for informants used purposive sampling with new interviews and interviews will be analysed using SWOT and FGD. The results that have been obtained from this study are the discovery of changes in behaviour before and during pandemic, with potential tourists who have consumptive behaviour with alternative types of tourism during the Post-Pandemic (New Normal). As well as efforts that must be built is to make the latest adjustments based on the needs of tourists by providing services and product facilities according to the New Normal standard. Both results can be used as new for each stakeholder to determine the direction of culture that is general in nature and is a necessity for every business actor in carrying out operations in the tourism sector.
\end{abstract}

Keywords-tourism, consumer behavior

\section{INTRODUCTION}

Tourism Constitution No. 10 of 2009 Chapter 20 states about the right each tourist gets; a) accurate information about tourism attractions, b) tourism services based on tourism standards, c) law and security protection, d) health services, e) personal rights protection, f) insurance protection for high-risk tourism activities. Furthermore, Chapter 23 states about the Government and Regional Governments obligations in; a) providing tourism information, law protection, security and tourists safety, b) creating a conducive climate to develop tourism business which equal opportunities in facilitating and providing law certainty, c) supervising and controlling tourism activities to prevent and overcome various negative impacts to wider community. Chapter 26 refers to employers to provide comfort, friendliness, security protection and tourists' safety, and maintain a healthy and clean environment. Based on the law above, the obligation of a tourist destination which has government cross-sectoral involvement and investor is to provide guarantees in all tourism activities in their region so that can gather trust in prospective tourists on a tour. Progress and development of tourism are depending on the ability of that region offers or provides tourists' safety and security. Its dynamic development is influence by external and internal factors of an area where they both will affect growth rate of tourism sector. The emergence of external issues such as SARA, disease, terrorists, can influence tourist visits level.

The pandemic of Covid-19 has proven that the number of tourists is decline. BPS (Central Bureau of Statistics) records in 2020, the biggest drastic decline of foreign tourists are happening in Singapore $33.12 \%$ and Malaysia $13.87 \%$, while tourists from China still rise to $17.58 \%$ due to the Chinese New Year on January 02 and the last component affected is hotel room rate of 49.17 point. Index of TPK (Room Occupancy Rate) decrease to 10.22 point (month to month) and 2.3 year on year, whereas foreign tourists who came to Indonesia increase to $9.5 \%$ last year. According to Indonesian Bank, the Minister of Maritime Affairs and Investment, Mr. Luhut B. Panjaitan said that the estimated detriment reached USS 500 million or almost Rupiah 7 trillion per month. Indonesian policy of tightening the entrance and exit of foreign tourists to Indonesia certainly does not completely harm tourism sectors. It is because potential tourists are not only foreign tourists, but also domestic. Encourage domestic tourists is one of the strategic ways to press number of tourists' visit reduction in last few months. Therefore, there is a needed to get and gather trust in traveling security aspect.

Based on the description above, the focus of this research is: 1) how does the impacts of tourists' behaviour changing in Kupang after Covid-19 in Indonesia? 2) How does the efforts to get potential domestic tourists' trust after the spread of Covid-19? The purpose of this research are to get result of tourists' behaviour changing impact and effort to build potential domestic tourists' trust in Kupang after the spread of Covid-19. The result this research can used as reference to East Nusa Tenggara Government and tourism stakeholders in determining tourism policies. This is a mix-method research [1] 
and uses Research and Development procedure of Borg and Gall [2].

\section{REVIEW LITERATURE}

\section{A. Purchase Decision Process}

The consumer behaviour held by a firm or organization in aim to finds consumer [3]. In tourism industry, this study also used to increase the tourist number [4-6].

The product purchase decision making is mainly affected by lots of motivations and factors. Swarbrooke and Horner [5] group it as internal and external factors. There are several of them that can be count on as variable to measure people wants (consumer behaviour). Those are; motivation, culture, age and gender, social class, lifestyle, lifecycle, and group references. In addition, all these factors are the most used by companies [7].

Kotler and Gary Armstrong [8], divide it into five stages:

1) Problem recognition: The buying process starts when the buyer recognize a problem or needs. These needs can be triggered by external stimuli and internal. Marketers need identify the triggering state certain needs. From introduction problem, marketers can develop marketing strategies can stimulate interest consumer.

2) Information search: Consumers who are intrigued by their needs will be compelled to search for more information. Resources the results obtained vary greatly accordingly with product categories and characteristics buyer.

- Personal sources: Family, friends-friends, neighbours, acquaintances.

- Commercial sources: Advertising, salespeople, distributors, packaging, store displays

- Public sources: mass media, institutions consumer.

- Source of experience: Handling, observation, and usage product.

3) Alternative evaluation: Evaluate alternatives in the process purchase decision making is the evaluation stage products and brands. Consumers differentiate product characteristics which ones are seen most relevant or stand out and will give great attention on products which will provide benefits searching for.

4) Buying decision: Consumers will form a purchase intent to buy a brand the most liked. Some factors can influence intent purchase and purchasing decisions according to Kotler and Gary Armstrong [8] is the attitude or position of people other factors and situations are not it is anticipated that the description as follows:

- The attitude or attitude of others. The existence of others can be influence purchasing decisions. The stronger the attitude of others to influence, and getting closer these other people with consumers, consumers will increasingly adjust the purchase intent.

- Unanticipated situation factors. Consumers form a purpose purchase based on factors like a financial income expected, expected price, and expected product benefits.

5) Behavior after purchase: After purchasing the product, the consumer will experience a level of satisfaction or certain dissatisfaction.

\section{B. SWOT Analysis}

SWOT analysis is used by companies to identify factors systematically and creates strategies [9]. Moreover, this kind of analysis is truly depending on logic that can maximize strengths and opportunities, as well as minimize weaknesses and threats.

SWOT ANALYSIS

\begin{tabular}{|c|c|c|}
\cline { 2 - 3 } \multicolumn{1}{c|}{} & Helpful & Harmful \\
\hline Internal origin & strengths & Weaknesses \\
\hline External origin & opportunities & Threats \\
\hline
\end{tabular}

Fig. 1. SWOT analysis.

\section{RESEARCH METHODS}

This research is a mix-method research [1]. The researchers used procedure of Research and Development that was developed by Borg and Gall [2] during its completion, which is exploring, implementing and disseminating. The researcher did adaptation and modification in doing its steps without reducing validity process and result of this research.

\section{A. Research Time and Place}

This research was conducted in Tourism Government of Kupang, located at El Tari II No. 72, Kupang. Furthermore, this research also conducted in some lodging accommodation such as hotel and tourism attractions in Kupang to be used as continued observation. This research was carried out until researchers discover saturation point in gathering data from the field. This research has been conducted for eight months, starts from June to October 2020

\section{B. Research Subject}

Subject of this research is the Head of Tourism Government. Furthermore, the researchers interview relevant parties and tourism businessman in Kupang represented by the Chairman of Institute, such as Chairman of HPI (Tour Guide Organization), PHRI (Hotel and Restaurant Association), and ASSITA (Tours and Travel Agencies), due to researchers considered that those organizations directly involved in the field to develop organizations in Kupang Tourism. Other subjects are 100 domestic tourists who visit Kupang tourism and use accommodation through questioner in gathering data research. 


\section{Research Instrument}

To get a valid data, an instrument is needed [10]. The researchers acted as data collector and instrument active to gather data in the field. Whereas other data gathering instrument besides human being are various devices (interview guidance, questioner, literature, et cetera).

\section{Data Analysis Technique}

This research used two types of research which are quantitative and qualitative using sequential explanatory. Therefore, quantitative analysis was used to explain first research problems, the scoring using Likert scale with SPSS as analysis tool and to answer second research problems using Matrix SWOT as analysis tool, then combine two research results in descriptive qualitative to determine follow up effort of the phenomenon occurred. In descriptive qualitative method, the researchers transform raw data into understandable data, including compose and present it so that becomes an accurate information [11].

\section{RESULTS AND DISCUSSION}

Changes in Consumer Behaviour (Tourists) in choosing products and services tourism business before and after pandemic (new normal) can be described as follows:

- The most preferred type of tourism before the pandemic is marine tourism, which consists of; beach, lake and sea. This type of marine tourism is also still popular with respondents, although the percentage is reduced when compared to before the pandemic, which is from 89 percent to 58 percent.

- The type of transportation that is often used by most respondents before the pandemic is land transportation. During the pandemic, this type of land transportation was still relied on for travel despite decreasing drastically, from 93 percent to 65 percent.

- Relating to accommodation in questioner is 32 percent choosing camp and home stay.

- Before pandemic, the respondents used to have meal in restaurants near beach, during pandemic price to have meal is more concerned by them.

- Travel agent used to provide beautiful new tourism object to visit before pandemic but during pandemic they tend to provide health protocol to do the trip.

\section{A. Efforts to encourage tourists to visit tourism object in} Kupang City

SWOT identification in this questioner about respondents' interest and interviews with stakeholders dealing with tourism, especially in Kupang City as follows:

1) Strength: (S1) Attractive cultural and natural tourism, (S2) Supporting accessibility, (S3) Good facility, (S4) Friendly local, (S5) Travel Agents and tour operators who aggressively organize outdoor activities; landscape, culture, natural conditions are our advantages, including local tourists. (Lelogama, Tablolong).

This report also supported by another research shown that marine tourism is one of the favourites attractions in Kupang $[12,13]$

2) Weakness: (W1) Not all tourism services concern to health protocol standards, (W2) Promotion of tourism businesses that have not focused on services according to new normal standards, (W3) Supervision about health protocol is uneven, (W4) People's purchasing power is still weak during the new normal period, (W5) Governor's order to close and open tourist sites is limited to five people in providing services, (W6) There are no partnership activities with fellow businessman during the pandemic, (W7) worse money circulation has an impact on the BANK, (W8) The average prospective tourist community strives to save money to maintain economic resilience, (W9) After the corona is free, it must still go through a recovery period. Tourism is considered tertiary but the community first pays attention to primary needs so that the economic awakening period still requires a long time, (W10) There has been no implementation of the new standard normal protocol from the government for every business engaged in tourism, (W11) There is no advertisement in website, and print media) that includes certification of human resources, tourism products (destinations, etc.), (W12) Not yet optimal management of new normal standard destinations especially new destinations with alternative tourism products, (W13) All sectors affected All tourist attractions are closed, (W14) The closure of tourist attractions as a result of the large number of tourism industry players whose businesses have not yet adapted to health protocol standards in the new normal period (preparing hand wash masks etc.).

3) Opportunity: (O1) The desire to travel is quite high but with caution, $(\mathrm{O} 2)$ The purpose of traveling is relatively close to shorter distances, (O3) The ability to adapt and new trends that lead to alternative tourism, (O4) Improve technologybased communication and information networks and accelerate the evolution of industry and digitization of all services, (O5) Digital marketing has become the new normal of both marketing tourism products and services, (O6) The existence of cooperation with national goals that lead to the rise of tourism in the new normal period, (O7) There are efforts in economic recovery in the new normal period, (O8) Increased awareness of tourism communities in providing alternative tourism services with quality health protocol standards, (O9) Open employment in the field of tourism for young people to be more challenged with creativity and independent innovation based on IT and local natural resources, $(\mathrm{O} 10)$ Corona virus outbreak rate is relatively low compared to other regions outside NTT, (O11) Better public 
knowledge about the real condition of tourist attractions in the area, (O12) The hotel in Kupang City is ready to assist the local government if an increase in patients affected by the corona virus if the hospital exceeds the ability to accommodate, (O13) Price strategy by giving discounts or discounts to reach people's purchasing power and tourists who are still unstable (low), (O14) NTT especially the city of Kupang has the ability to survive in economic aspects (There is no industry so there are no employees who are laid off on a large scale, our economy is supported by civil servants because we are civil servants with a simple lifestyle), (O15) Banks and taxation provide relief in the repayment of capital loans for entrepreneurs, including entrepreneurs engaged in tourism, (O16) Enthusiastic community is very high (especially the millennial) in welcoming the new normal era as evidenced by the rise of alternative tourism activities, (O17) The awareness and ability of each service business actor in the tourism sector before being truly ready to carry out marketing in an effort to adapt to adjust the shape, volume, safety equipment, carrying capacity according to the new normal era before marketing products and services to consumers (tourists), (O18) There is a plan from the relevant government (tourism agency) to issue a policy on standardization in the form of New Normal Certification to every tourism entrepreneur which is engaged in the tourism sector as a form of response to readiness to face the new normal era, (O19) Each tour operator already has market specifications except those that are still new (the target market is still in general), (O20) There has been a response in the form of support to help the mode of transportation, intestine for short time travel (from airports and ports) with adequate service standards and transportation facilities (health standards), (O21) The existence of PERWALI rules (regarding hotel restaurants and tourist attractions) in controlling tourism activities in the new normal period, (O22) The existence of central government support (Ministry of Tourism) budgeted a directed budget for handling pandemics (non-physical funds) in the form of assistance for employees affected and empowerment activities (Tour guide training and Strengthening human resources), (O23) There is a Webinar trend in every cross-sectoral and cross-disciplinary cooperation and communication activity.

4) Threats: (T1) both safety and health service are not optimal yet, (T2) The condition of a country is economically weak, (T3) There are still increasing cases of pandemic corona.

These threats mean the negative impacts caused by the pandemic. There are many sectors including tourism industries going down caused by the COVID 19 issues [14-16].

This is also the case for many other tourism destinations around the world. A recent news article on COVID 19 effects on Canada's Banff National Park suggests that the adventure tourism destinations will have to rethink their business-as-usual approaches going into the future [17].

\section{B. Strategies to Build Trust of Potential tourists Candidates} in Kupang City

1) $\mathrm{SO}$ (Strength, Opportunity)

- Creating new alternative tourism products to increase IT-based marketing, for consumers who are not too far away and time-consuming with health protocol standards. (S1), (S2), (S3), (S4), (O1), (O2), (O3), (O4), (O5), (O7), (O8), (O10), (O11) Optimizing the communication network to the point that potential alternative tourism activities (O9), (S1), (S2), (S3), and (S4).

- Tour advertisement leads to outdoor activities; which utilizes landscape, culture, and nature to our advantage, including local tourists. (example: Lelogama and Tablolong)

- Utilizing outdoor landscape such as camping destination (for examples: restoring Fatukopa and other destinations).

- Encourage the people especially millennial to improve the management and HR management, alternative tourism (By looking at the community's enthusiasm is very high and appreciation from the government and private sector).

- Each tour operator that already designed a market specified marketing collaboration with a new tour operator to set product specifications towards alternative tourism to reduce general tourism products (mass tourism).

- Keep doing independent promotion and partnerships (government, private sector, tourism community especially attractions or alternative tourism-based tourism products must continue to run.

\section{2) WO (Weakness, Opportunity)}

- Travel agent and tourist must apply strict health protocol standards from home to tourism place including service provided (W1), (O8).

- Running marketing based on health procedure to convince tourists (W2), (W3), (O3), (O4), (O6), (O8)

- Attaching license and business certification mark that fulfils the health standard protocol requirements as well as previous tourist testimonials printed (W2), (W3), (O3), (O4), (O6), (O8), (O9), (O11).

- Discounts for tourists who are involved in helping with promotion (W2), (W4), (O3), (O4), (O5), (O7), (O8), (O10).

- Partnership activities and cooperation with the Penta helix method with fellow government and community businesses during the pandemic. 
- Conducting training and empowerment of destination management with competency standards in accordance with the characteristics of the destination and the needs of tourists towards alternative tourism.

- Encourage millennial generation to aggressively create attractions or creative and innovative alternative tourism products that can compete at the local, national and even international level in welcoming new eras or new eras in adapting to the latest developments or trends while maintaining the satisfaction of tourists.

- The existence of PERWALI to monitor tourist attractions, restaurants, hotels, etc.

\section{3) ST (Strength, Treat)}

- Utilizing IT-based communication networks and other information media in the tourism area to continue to supervise and inform tourists and businesses to continue providing services and facilities according to health protocol standards.

- Working closely with the hotel to help local governments manage patients.

- In carrying out promotions and providing tourist facilities services, mandatory certification of health protocol and performance management (HR) standards must be included.

- The activity of the tour that utilizes attractions related to the physical tourist needs to be regulated according to age, distance (tracking), accessibility conditions and facilities that are tailored to the ability and physical endurance of the tourists with the aim of maintaining immunity and safety of tourists while still paying attention to cleanliness.

- It is necessary to support academics in conducting socialization which is preceded by research or community studies to open mindsets about the readiness of the community at the destination and the strategy to see the weather climate, adapted to local characteristics to bring new alternative products with the theme of tourism on a small scale.

- Product packaging for new alternative tourism packages by combining the old tourist attraction in the city but with more dominance than alternative tourism outside the city while in the city with a small proportion.

\section{4) WT (Weakness, Treat)}

- Penta helix communication while still utilizing IT advancements in cross-sectoral coordination to avoid the risk of spreading corona (zoom meeting)

- Changing the shape or renewing in terms of the volume reduced by considering the carrying capacity), safety equipment, and ensuring that the products and services to be marketed are truly ready to be consumed by the market (tourists)

- New Normal Certification is needed for each product and service and periodic or periodic control (management control, periodic repit labor) as a form of readiness and anticipation or prevention of the possibility of adverse impacts will occur in tourist activities.

- Maintain the target market and expand the target market.

- Budget allocation is directed towards handling nonphysical fund pandemics as the top priority.

- Training should be held for managers on the use of safety equipment, local guide training with the theme of alternative tourism, especially in the detection of new alternative tourism.

- Ministry of tourism distributes stimulus for hotel employees affected.

- Strengthening alternative tourism human resource training.

- The participation of SOEs to help standardized tourism transportation capital as a stimulus to trigger the growth of competitors for the transportation industry services that have been able to provide similar services that have the same standard, especially for short-time trips from the port or airport to the nearest tourist attractions

Based on the two analysis results above, in determining consumer behaviour activities is an important factor in understanding the characteristics of the market in accordance with the needs of tourists who are dynamic. Consumer (tourist) behaviour can be influenced by internal and external factors where the internal factors come from motivation, culture, age and gender, social class, lifestyle, lifecycle, and reference groups owned by domestic tourists who come in Kupang while the external factors it is a condition that is able to influence consumers in making a decision to choose a product, both physical and service where the external factor in question is the outbreak of the corona virus that is able to influence it. So in addressing this strategy needs to be done in taking steps to determine effective and efficient marketing activities by doing; product development that suits the needs of tourists in Kupang City that leads to alternative tourism in nature, besides that it requires a marketing strategy of the product through cooperation and cross-sectoral partnerships (Penta helix) and a technology-based promotion strategy that promotes health standard certification in the new period normal as part of adaptation and renewal in the world of tourism in order to increase trust for consumers (tourists).

\section{CONCLUSION}

Based on the results obtained it can be concluded that there has been a change in the consumptive behaviour of tourists in 
choosing and using the services, products and facilities provided caused by the process of adaptation to the new normal period so that the effort that needs to be done is diversification of products and services according to the characteristics of the needs tourists in the new normal period by all stakeholders involved in tourism activities.

\section{REFERENCES}

[1] J.W. Creswell, Research design pendekatan kualitatif, kuantitatif dan mixed. Terjemehan fawaid, Yogyakarata: Pustaka Pelajar, 2014.

[2] W.R. Borg and M.D. Gall, "Educational Research: An Introduction," Fifth Edition. Longman: New York, 1990.

[3] J.A. Howard, Consumer behavior in marketing strategy, Prentice Hall, 1989.

[4] T. Choibamroong, "Knowledge of tourists' behavior: A key success factor for managers in tourism business," International Journal of Tourism Research, vol. 1, pp. 1-8, 2006.

[5] J. Swarbrooke and S. Horner, Consumer Behavior in Tourism, Elsevier, 2007.

[6] D. Fratu, Factors of Influence and Changes in The Tourism Consumer Behaviour, Bulletin of the Transilvania University of Braşov: Economic Sciences, 2011.

[7] D. Hudson, Agricultural Markets and prices, USA, UK and Australia: Blacwell publishing Ltd., 2007.
[8] P. Kotler and G. Armstrong, Principles of marketings. Prentice Hall Of India, 2001.

[9] O.C. Ferrel and D. Harline, Marketing Strategic. South Western, Thomson Corporation, 2005.

[10] L.J. Moleong, Metodologi Penelitian Kualitatif, Rosdakarya: Bandung, 2010.

[11] E.S. Kusmayadi, Metodologi penelitian dalam bidang kepariwisataan. Jakarta: Gramedia Pustaka Utama, 2000.

[12] S.R. Sanam and I.M. Adikampana, "Pengembangan Potensi Wisata Pantai Lasiana sebagai Pariwisata Berkelanjutan di Kota Kupang, Provinsi Nusa Tenggara Timur," Jurnal Destinasi Pariwisata, vol. 2, no. $1,2014$.

[13] M. Overbeek and R. Naatonis, "Sistem Rekomendasi DestinasiWisata di Kota Kupang dengan Metode Weighted Product," Jurnal HoaqTeknologi Informasi, vol. 10. no. 1, 2019.

[14] A. Hoque, F. Shikha, W. Hasanat, I. Arif, and A. Abdul, "The Effect of Coronavirus (COVID-19) in the Tourism Industry in China," Asian Journal of Multidicilinary Studies, vol. 3, no. 1, 2020.

[15] P. Patel, J. Sharma, S. Kharoliwal, and P. Khemariya, "The Effect of Nobel Corona Virus (Covid-19) in The Tourism Industry in India," International Journal of Engineering Research \& Technology, vol. 9, no. $05,2020$.

[16] M. Kamruzzman, "Tourism after Corona: Impacts of COVID 19 Pandemic and Way Forward for Tourism, Hotel and Mice Industry in Sri Lanka," Virginia Tech, Pamplin College or Business, 2020.

[17] N. Macdonald, "A ghost town: with tourist access cut off, Banff unemplotment soars," The Globe and Mail, 2020. 